\title{
Less-skilled learners benefit more from metacognitive instruction to develop listening comprehension
}

\author{
Bozorgian, Hossein $\bowtie$ \\ University of Mazandaran, Iran (h.bozorgian@umz.ac.ir)

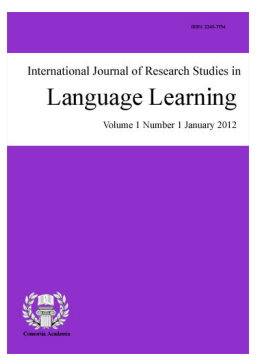

ISSN: 2243-7754 Online ISSN: 2243-7762

OPEN ACCESS

\section{Abstract}

A growing interest in using metacognitive instruction to develop listening comprehension has emerged for almost two decades. This paper investigates the impact of metacognitive instruction on less-skilled and more-skilled learners' listening comprehension. Thirty-two female adult, Iranian, intermediate level English as a Foreign Language (EFL) learners participated in a 'strategy-based' instruction, planning, monitoring and evaluation. Each of three metacognitive strategies focused on promoting learners' comprehension of International English Language Testing System (IELTS) listening texts. A comparison of pre- and post-test scores showed that the less-skilled learners benefited more from metacognitive instruction than more-skilled learners in IELTS listening tests.

Keywords: metacognitive strategies; metacognitive instruction; listening comprehension; strategy-based instruction; EFL 


\section{Less-skilled learners benefit more from metacognitive instruction to develop listening comprehension}

\section{Introduction}

Managing listening instruction and improving listening comprehension in the classroom are difficult for teachers and EFL learners. This difficulty leads to frustration, poor learners' performance or their inadequate attention to listening instruction in the classroom. This is because the process of listening comprehension is complex, and needs a listening lesson aligning with a strategy-based instruction to control the listening comprehension. The complexity of listening comprehension may involve external factors related to a speaker, text and/or content. These factors: new expressions, speech rate, accent, unfamiliar content and cultural references increase the difficulty of listening message being understood (Lynch, 2011). Further, focusing on the product of listening comprehension in research is another factor for increasing the difficulty of listening comprehension of second language learners. To reduce the complexity of listening comprehension for less-skilled learners, 'metacognitive instruction' is used to control the process of listening comprehension. Managing the process of listening comprehension through metacognitive instruction using a strategy promotes the outcome of listening comprehension (Bozorgian, 2014; Vandergrift \& Tafaghodtari, 2010). Thus, the focus of this study is to examine whether metacognitive instruction benefits less-skilled and more-skilled learners' listening comprehension.

\section{Metacognition}

The term 'metacognition' is often simplified as thinking about thinking or cognition about cognition. Flavell first coined the term metacognition and defined it as 'knowledge concerning one's own cognitive processes and products or anything related to them' (Flavell, 1976, p. 232). He deconstructed this term into three different kinds of metacognitive knowledge:

$>$ Person knowledge (the knowledge a person has about him or herself and others as cognitive processors),

$>$ task knowledge (the knowledge a person has about the information and resources they need to undertake a task) and

$>\quad$ strategy knowledge (knowledge regarding the strategies which are likely to be effective in achieving goals and undertaking tasks).

Wenden (2002) suggests that metacognitive knowledge is a stable body of knowledge, though, of course, it may change over time, as one acquires cognitive maturity and experience. Like other aspects of socialization, this knowledge may often be acquired unconsciously through observation and imitation, or consciously, as learners listen to teachers, parents, or peers providing them with advice about how to learn. Metacognitive knowledge allows problem solvers to better encode and represent the assumptions in a problem context and therefore better perform (Davidson \& Sternberg, 1998). It is not only about the metacognitive knowledge that problem solvers use, but also about the problem solvers' knowing when and how to use metacognitive knowledge. When problem solvers have metacognitive knowledge, they represent an awareness and regulation of their mental process, which helps them gain new knowledge (Griffith \& Ruan, 2005). Since metacognition functions as a key to facilitate comprehension, it should be a valuable component of classroom instruction for second language learners.

\subsection{Strategy-based instruction}


Vandergrift (2004) mentioned the cognitive process of listening comprehension and suggested that listening comprehension is the most difficult language skill because it is the least explicit among four language skills. Some studies (Lynch, 1988; Mendelsohn, 2001; Rost, 2002) focused on the top-down and bottom-up strategies in listening comprehension. Top-down strategy is used when learners use context and prior knowledge (topic, genre, culture, and other schema knowledge in long-term memory) to build up a conceptual framework for comprehension. Bottom-up strategy happens when learners gradually create meaning by connecting larger units of meaning from phoneme-level up to discourse features (Vandergrift, 2004). Clearly, listening comprehension is a temporary and fleeting process, which demands learners keep altering their assumptions during the stream of the oral input (Field, 2008).

Researchers, such as Goh (2002) and Hulstijn (2001) suggested that listening strategy instruction should not be taught discretely but integrated with regular listening activity so that students would be willing to follow learning theory in conjunction with linguistic features. Another study conducted by Herron, Cole, York, and Linden (1998) focused on top-down strategy of listening comprehension in a foreign language. Two advance organizer conditions (declarative and interrogative) were compared through the student retention of information in foreign language videos. College students $(n=67)$ participated in five groups (four experimental groups and one control group) of a beginning-level French course. The teacher read aloud six sentences that summarized, in chronological order, major scenes in the upcoming video in declarative conditions. Further, the teacher began by reading aloud the same six sentences, but this time each declarative sentence had been transformed into a question in the interrogative condition. For each question, the teacher suggested three possible answers, making no indication as to which one was correct. The control condition consisted of a group of students who watched the same videos as in the declarative and interrogative conditions, but had no advance organizer before the video viewings. The finding shows that there were no significant differences in scores between the two experimental groups, though students in both declarative and interrogative conditions scored significantly higher on the tests than did the control group.

In addition to the impact of interactive bottom-up and top-down strategies on listening performance, the language proficiency affects the application of each. For instance, VanPattern (1995) examined the correlation between linguistic proficiency and top-down and bottom-up strategies. A narrative passage was given to three Spanish groups: first, fourth semester and third year university students who had conversation courses. They were given four tasks: i) the first task involved listening content only; ii) the second task involved listening for both content and a word-final morpheme; iii) the third task involved listening for content and separate morphemes; and iv) the fourth task involved listening for content and a key word. The finding indicates that a significant effect emerged from the interaction between level and task. The researcher discovered that as learners had problems to concentrate well on form and content, they initially shifted their attention to meaning to draw comprehension.

Increasing better listening awareness of less-skilled learners requires following a strategy-based instruction, a set of rules and regular opportunities to tackle listening problems strategically. Learners are to be provided with enough opportunities to act upon the set of rules already devised by the teacher. This regulated procedure helps learners plan, monitor and evaluate their listening (Bozorgian, 2012; Goh, 2008; Vandergrift \& Tafagodtari, 2010). The sequence of listening tasks helps learners analyze the listening input thoroughly to understand the message. Thus, this study aims to investigate the impact of metacognitive instruction on less-skilled and more-skilled learners' listening comprehension.

\subsection{Metacognitive instruction in listening}

Metacognitive instruction increases learners' awareness of their listening and this awareness benefits their knowledge of choosing a suitable strategy to facilitate learning ability (Goh, 2008). Three classroom-based research focused on the metacognitive instruction has indicated that metacognitive instruction benefits less-skilled learners' performance. First, Cross (2011) conducted a small-scale study of the effect of 
metacognitive instruction on a group of twenty Japanese advanced EFL learners' comprehension over five listening lessons. The listening lessons included predicting, monitoring, problem identification, and evaluating in each of five listening lessons to improve learners' comprehension performance of television news items.

The results from pre- and post-test scores illustrated that three of four less-skilled learners made substantial gains across five lessons, whereas only one of four more-skilled learners improved. Second, Vandergrift and Tafagodtari (2010) measured the listening comprehension of 106 tertiary-level high-beginner and lower-intermediate learners of French as an L2 over a semester. 59 students from the experimental group listened to texts using a methodology that led learners through the metacognitive processes, (prediction/planning, monitoring, evaluating, and problem solving) underlying successful L2 listening. The same teacher taught 47 students from the control group, and students listened to the same texts the same number of times, but without any guided attention to process.

The findings from a pre-test and post-test scores show that the less-skilled learners participated in the guided methodology (strategy-based) benefited more than more-skilled learners. Finally, Goh and Taib (2006) conducted a small-scale study to assess the development of a group of ten Chinese primary schools, ESL learners over eight listening lessons. The eight listening lessons consisted traditional listening exercises, individual post-listening reflections on their listening experience, and teacher-facilitated discussions that focused on specific aspects of metacognitive knowledge about listening. The results from a pre-test and post-test indicated that the less-skilled learners reported increased motivation, confidence and strategy knowledge, and one of the more-skilled learners failed to improve across the study. The findings of the studies above show that a strategy-based approach in the classroom is effective for learners to develop listening comprehension.

There has been a growing interest for almost two decades in using metacognitive instruction to facilitate the outcome of listening. Goh (2008) maintains that metacognitive instruction inherently strengthens learners' awareness and their listening process, which helps learners use appropriate strategies. The demand for such metacognitive instruction is that learners need a long-term direct explanation, modelling strategies and strategies with guided practice (Pressley, 2002). The pedagogical evidence show that metacognitive instruction assists learners in: i) what successful learners choose to select for processing learning, and ii) improving successful language learning through acquiring metacognitive strategies. One such way is to take the process of listening that involves learners with a listening lesson consisting planning, monitoring and evaluation. Given the significance of metacognitive instruction as an indicator of listening development, the aim of this small-scale study is to find out whether metacognitive instruction benefits less-skilled and more-skilled EFL learners' listening comprehension.

Does metacognitive instruction benefit less-skilled and more-skilled learners' listening comprehension?

\section{Method}

\subsection{Participants}

A group of 32 Iranian females aged between 18 and 25 years attended an English as a Foreign Language class took part in this study. Out of the total 35 enrolments for this class, three learners declined to take part in either the pre-test or post-test listening administration. All were attending an intermediate level English language course based on the English language institute, which is nearly equivalent to IELTS 5. Metacognitive instruction was not in practice for the learners in their regular classroom in the English language institute. Learners themselves chose their learning partners to practice the listening activities in a group. The teacher was male, 31 years old and had approximately 8 years of EFL teaching experience.

\subsection{Materials for strategy-based instruction through metacognition}


Less-skilled learners benefit more from metacognitive instruction to develop listening comprehension

The materials used in listening activities should feature authentic and natural everyday speech. Field (2000) suggests that listening activities at beginner, elementary and intermediate level should be authentic and take the following two points into considerations. First, learners should be carefully briefed so that they feel comfortable about being exposed to listening texts where they may have problems understanding the message. Second, teachers should grade the difficulty of tasks to fit it to the comprehension level of the learners rather than grading the text so that learners would be able to achieve it. Therefore, the listening materials used in each of the lessons were natural and based on the recoded IELTS listening texts. The choice of the IELTS listening texts was based on the view that the intermediate learners participated in this study intended to take the IELTS test in near future. The purpose of their English language learning was to continue their education in one of the English countries. All the recorded IELTS listening texts for four lessons were approximately from one and a half to two and a half minutes long and were presented on an audio CD player in short segments.

Each of the four listening activities was 100 minutes long for two sessions (50 minutes each) in a week, and involved a strategy-based instruction (Vandergrift \& Tafaghodtari, 2010). Of the 100 minutes metacognitive instruction, the teacher involved in the interaction with the learners around 15 minutes to facilitate their listening activities. This explicit sequence of listening tasks helped learners promote their knowledge of listening text, but was foreign to most of the learners and they learnt some of the missing segments from sharing notes with their peers. This strategy-based instruction helped them remove their potential opposition and realized why they were doing what they were doing and involved the listening activities. A good lesson learnt by the students is to experience learning from their errors, which enable them to take further risks in learning.

The sequence of the tasks, which was based on Vandergrift's (2004) study consisted of five main stages (see Figure 1) and the strategy-based instruction described below was the same for all four lessons:

\begin{tabular}{|c|c|}
\hline Stage of listening instruction & Related metacognitive strategies \\
\hline \multicolumn{2}{|l|}{ Planning/predating stage } \\
\hline $\begin{array}{l}\text { 1. Once students know topic and text type, they } \\
\text { predict types of information and possible words } \\
\text { they may hear. }\end{array}$ & Planning and directed attention \\
\hline \multicolumn{2}{|l|}{ First verification stage } \\
\hline $\begin{array}{ll}\text { 2. } & \text { Students verify initial hypotheses, correct as } \\
\text { required, and note additional information } \\
\text { understood. }\end{array}$ & Monitoring \\
\hline $\begin{array}{l}\text { 3. Students compared what they have written with } \\
\text { peers, modify as required, establish what needs } \\
\text { resolution and decide on details that still need } \\
\text { special attention. }\end{array}$ & Monitoring, planning, and selective attention \\
\hline \multicolumn{2}{|l|}{ Second verification stage } \\
\hline $\begin{array}{l}\text { 4. Students verify points of disagreement, make } \\
\text { corrections, and write down additional details } \\
\text { understood. }\end{array}$ & Monitoring and problem solving \\
\hline $\begin{array}{l}\text { 5. Class discussion in which all contribute to } \\
\text { reconstruction of the text's main points and } \\
\text { most pertinent details, interspersed with } \\
\text { reflections on how students arrived at the } \\
\text { meaning of certain words or parts of the text. }\end{array}$ & Monitoring and evaluation \\
\hline \multicolumn{2}{|l|}{ Final verification stage } \\
\hline $\begin{array}{l}\text { 6. Students listen for information that they could } \\
\text { not decipher earlier in the class discussion. }\end{array}$ & Selective attention and monitoring \\
\hline Reflective stage & \\
\hline $\begin{array}{l}\text { 7. Based on discussion of strategies used to } \\
\text { compensate for what was not understood, } \\
\text { students write goals for next listening activities }\end{array}$ & Evaluation \\
\hline
\end{tabular}

Figure 1. Listening instruction stages and related metacognitive strategies Vandergrift (2004)

$>$ In stage one, students were introduced to the meaning of a few key words and then were familiar with 
the topic of the discussion. This topic familiarity functions as advance organizations helping learners to direct their attention to the content of the listening texts.

$>$ In stage two, students listened to the recorded listening text and at the same time took some notes. Exchanging their notes with peers helped them monitor, modify and establish their assumptions. The taking notes assisted students in improving the selective attention.

$>$ In stage three, students needed to verify their assumptions through a group and class discussion. This stage helped students to redirect their attention to the certain points in the recorded listening required for further comprehension.

$>$ In stage four, as students listened for the second time, they confirmed those information missed in the first time listening and identified those points discussed in pairs and group earlier through a careful monitoring. This explicit sequence of listening tasks in this stage was aligned with sharing, discussion, and evaluation recommended by Goh and Taib (2006).

$>$ In stage five, students had a reflection on the procedure undertaken in their diary so that it functions as a model for improving their listening comprehension.

\subsection{Instrument}

The instrument used to examine the learners' listening comprehension in the pre- and post-test was a practice IELTS listening test. IELTS listening tests, developed by Scovell, Pastellas, and Knobel (2004), consisted of four components and each with ten questions. Like the nature of listening activities, IELTS listening tests closely focus on daily conversation, public speech, academic discussion, and academic lecture.

\subsection{Data collection}

To achieve the aim of this study and follow Vandergrift's $(1997,2003)$ taxonomy, the learners' performance in IELTS listening tests in pre- and post-test scores are compared in terms of the number of correct answers. The teacher guided through four listening lessons based on the recorded listening texts of the daily conversation (lesson one), public speech (lesson two), academic discussion (lesson three), and academic lecture (lesson four). The focus of the listening lessons was one-way and all classroom interactions were conducted in English. The learners were directed and encouraged to use metacognitive strategies (planning, monitoring and evaluation) when approaching the recorded listening texts. The learners listened once to the pre-test and post-test, as it was allowed to listen once in their mid-term and final in the language institute as well as the real time IELTS test administration. Each pre-test and post-test of listening took approximately 30 minutes and the learners were given another 10 minutes to transfer their answers to their answer sheet. The lapse of time between pre-test and post-test was eight weeks.

\subsection{Data analysis}

The pre-test and post-test listening was first marked by a reference to the answers specified by the learners. To ensure maximum reliability, the exam board's regulations required strict adherence to these forms regarding both wording and spelling (Field, 2009). The learners were rewarded a mark in any three-word phrase, where they missed a letter or misplaced a letter. Wilcoxon signed-rank test were used to analyze the data, as it is a non-parametric test alternative to the paired sample t-test (Larson-Hall, 2010). Pseudonyms were used for learners in this study.

\section{Results}

Table 1 shows the learners' performance in the pre-test and post-test. Overall, the learners in the post-test benefited their listening comprehension, suggesting that metacognitive instruction had a significant effect on the 
intermediate learners' listening comprehension, $\mathrm{p}$-value $(p<0.05)$. To respond to the research question focusing on the effect of metacognitive instruction on learners' listening comprehension, the learners were divided into two groups: less-skilled and more-skilled learners based on the median in the pre-test. Five less-skilled and five more-skilled learners whose raw scores in the pre-test fell extreme above and below the median (58.00) were considered.

Table 1

Paired sample test

\begin{tabular}{lccccc}
\hline & $M$ & $S D$ & Median & $d f$ & P value \\
\hline Pre-test & 59.64 & 11.06 & 58.00 & 31 & $>.00$ \\
Post-test & 65.71 & 9.76 & 67.00 & 31 & \\
$\mathrm{~N}$ & & & 32 & & \\
\hline
\end{tabular}

Table 2 presents less- and more-skilled learners' pre-test and post-test performance. A Wilcoxon signed-rank test showed that eight weeks, once weekly metacognitive instruction did not elicit a statistically significant change in more-skilled learners' listening comprehension existing with $(\mathbf{Z}=-1.35, p=.17)$. Whereas, a Wilcoxon signed-rank test showed that eight weeks, once weekly metacognitive instruction did elicit a statistically significant change in less-skilled learners' listening comprehension existing with $(\mathbf{Z}=-2.02, p=.04)$. As EFL learners in this study lived in a country where English language has no acknowledgement out of the classroom and more- and less-skilled learners did not use English language for communication purposes. Therefore, the less-skilled learners' progress in listening performance can be linked to the instruction of metacognitive strategies, though the ceiling effect for more-skilled learners should not be disregarded.

Table 2

Wilcoxon signed rank test of less- and more-skilled learners

\begin{tabular}{|c|c|c|c|c|c|c|}
\hline Ranks & & $\mathrm{n}$ & $\begin{array}{c}\text { Mean } \\
\text { rank }\end{array}$ & $\begin{array}{c}\text { Sum of } \\
\text { ranks }\end{array}$ & $Z$ & $\begin{array}{c}\text { Asymp. Sig. } \\
\text { (2-tailed) }\end{array}$ \\
\hline \multirow{4}{*}{$\begin{array}{l}\text { Less-skilled pre- and } \\
\text { post test }\end{array}$} & Negative ranks & 0 & .00 & .00 & \multirow[t]{2}{*}{-2.02} & \multirow[t]{2}{*}{$>.04$} \\
\hline & Positive ranks & 5 & 3.00 & 15.00 & & \\
\hline & Ties & 0 & & & \multirow{6}{*}{-1.35} & \multirow{6}{*}{$<.17$} \\
\hline & Total & 5 & & & & \\
\hline \multirow{4}{*}{$\begin{array}{l}\text { More-skilled pre- and } \\
\text { post-test }\end{array}$} & Negative ranks & 1 & 2.50 & 2.50 & & \\
\hline & Positive ranks & 4 & 3.13 & 12.50 & & \\
\hline & Ties & 0 & & & & \\
\hline & Total & 5 & & & & \\
\hline
\end{tabular}

In brief, the results show that five less-skilled learners made a considerable amount of progress across the study and made more gains in the post-test than the more-skilled learners did. The next section will discuss the results of this study.

\section{Discussion}

The data of this small-scale study showed that although the more-skilled learners made progress slightly across the study, their progress was not as much as what the less-skilled learners gained across the study. The EFL learners in this study were provided with the four listening lessons in a strategy-based instruction for the purpose of promoting their listening comprehension. The results showed that five less-skilled learners made a considerable amount of progress in the listening comprehension across the study.

Putting more time on tracing down the meaning of an unfamiliar word hindered the learners from using strategies to achieve more comprehension. Therefore, using a strategy-based instruction in listening comprehension requires learners to have enough time to apply the strategies already instructed the sequential tasks. Thus, learners in this study went through metacognitive instruction for an eight week interval, which is sufficient for using the same test without inducing systematic variance in the data (see Bozorgian, 2014; Cross, 
2011).

One reason for students' agonizing feeling over their listening comprehension is the low profile of attention paid to the cognitive nature of listening comprehension tasks in comparison with other three language skills in the classroom. This is because the process, instruction and assessment of second language listening comprehension is less perceived and researched than other three skills. A strategy-based approach does not change the guiding principle that the learners must do a lot of listening, and notes from the onset that not everything taught will be considered the form of strategy instruction (Mendelsohn, 2006). However, metacognitive instruction, using pedagogical cycle (predicting, monitoring, problem identification, and evaluation) provides less-skilled learners with guides and support towards improving their listening comprehension ability (Cross, 2011).

Teaching metacognitive strategies, such as planning, monitoring and evaluation assisted the less-skilled learners further than the more-skilled learners in this present small-scale study. The listening lessons using the strategy-based instruction help learners enlarge their working memory capacity to embrace more language chunks for future recall. Using the listening lessons with the pedagogical cycle for L2 listening helps the less-skilled learners deal with authentic materials in an interesting way at the beginning of the strategy instruction (Bozorgian, 2014; Vandergrift \& Tafaghodtari, 2010). This is because the less-skilled learners benefit from the technique Wilson (2003) has called 'discovery listening'. This technique helps the less-skilled learners direct to: i) focus on their precise listening problems, ii) find out the reasons for the problems, and iii) evaluate the importance of the problems. The less-skilled learners' listening development should not go unnoticed in the classroom or this development goes awry after short time, as their cognitive knowledge is limited and needs to be developed. The teacher should highlight the less-skilled learners' listening development and keep encouraging the learners to reflect on their listening. The teacher encouragement assists the learners to build up with listening bricks to form good listening comprehension.

The results indicated that five more-skilled learners did not benefit from the metacognitive instruction across four listening lessons in a strategy-based approach. This might be because more-skilled learners relied more on the top-down strategies in the post-test or might be on the horn of dilemma to use whether top-down or bottom-up strategies. Cross (2011) suggests that the more-skilled learners reach out a solid level of understanding of acting out the bottom-up and top-down strategies, so the metacognitive instruction does not have a noticeable impact on their listening comprehension.

The purpose of a strategy-based approach was to seek for the essential need to implement needs analysis and this approach shows what needs to be taught and where the learners are in terms of their proficiency level (Mendelsohn, 2006). The listening lessons in this study helped the less-skilled learners benefit listening comprehension, as the less- and more-skilled learners required knowing the cause of the listening problems, sharing their listening problems with their peers, and practising the strategies in a sequential way. Therefore, the results of this present study support those of Cross (2011), Vandergrift and Tafaghodtari (2010), and Goh and Taib (2006), suggesting that metacognitive instruction using strategies benefits the listening comprehension ability of less-skilled learners. This potential listening progress drawn from the strategy-based instruction will aid the learners to deal with their future listening texts.

However, this study is different with the previous studies in terms of i) learners' language proficiency, ii) listening materials used for instruction, and iii) measuring the listening performance. First, the learners in this study were Persian adult EFL with an intermediate level, whereas the learners in Cross', Goh and Taib's (2006), and Vandergrift and Tafaghodtari's (2010) involved Japanese advanced, Chinese ESL, and French high-beginner/ low-intermediate, respectively. Second, the listening materials used in this study were only aligned with IELTS listening component contents (daily conversation, public speech, academic discussion, and academic lecture). In contrast, Cross (2011) used BBC television news items, and Goh and Taib (2006), and Vandergrift and Tafaghodtari (2010) utilized a variety of listening texts for the learners in the classroom. Finally, the tool used to 
assess the learners' pre-test and post-test performance for this present study was practice IELTS listening tests, whereas the studies above used standardized teacher-made tests, which were in parallel with the listening materials used for the metacognitive instruction.

\section{Conclusions and Implications}

This small-scale study used IELTS listening texts and examined less- and more-skilled learners' listening comprehension in the EFL context. The results provide some empirical support for the notion that metacognitive instruction using planning, monitoring and evaluation can be helpful for guiding and assisting less-skilled learners in developing their listening comprehension. In particular, the results suggest that less-skilled learners can benefit more than more-skilled learners from such a strategy-based instruction. If the fact is accepted that less-skilled learners need some further pedagogic support to benefit listening comprehension, a classroom curriculum needs to be revised to add sequential tasks of listening lessons to explicitly instruct this basic skill in the classroom. Teachers in the EFL classrooms can use a strategy-based instruction to L2 listening, which makes authentic materials more accessible to students. This approach makes learning for less-skilled learners more interesting and relevant to the purpose of the classroom. However, the limitation of this small-scale study is, first the inability to explore the learners' strategies already used for listening comprehension. Next, a median split on the basis of the pre-test results was done despite considering the primary concerns about this method, as the performance of only 5 test takers in each group was measured. Thus, the finding of this small-scale study critically narrows the generalizability of the results. Future studies should have a control group to test whether the development of listening performance is due to the metacognitive instruction, and provide information concerning the level of metacognition each learner had at the beginning and end of the study. This knowledge of learners' strategies assists teachers in working on what needs to be emphasized to benefit L2/EFL listening performance.

\section{References:}

Bozorgian, H. (2014). The role of metacognition in the development of EFL learners' listening skill. International Journal of Listening, 28, 1-13.

Bozorgian, H. (2012). Metacognitive instruction does improve listening comprehension. ISRN Education, 2012, 1-6. http://dx.doi.org/10.5402/2012/734085

Cross, J. (2011). Metacognitive instruction for helping less-skilled listeners. ELT Journal, 65(4), 408-416. http://dx.doi.org/10.1093/elt/ccq073

Davidson, J. E., \& Sternberg, R. J. (1998). Smart problem solving: how metacognition helps. In D. J. Hacker, J. Dunlosky, \& A. C. Graesser (Eds.), Metacognition in theory and practice (pp. 47-68). Mahwah: Erlbaum.

Field, J. (2009). The cognitive validity of the lecture-based question in the IELTS listening paper. IELTS Research Reports, 9, 17-65.

Field, J. (2008). Guest editor's introduction emergent and divergent: a view of second language listening research. Systems, 36, 2-9. http://dx.doi.org/10.1016/j.system.2008.01.001

Field, J. (2000). Finding one's way in the fog: listening strategies and second-language learners. Modern English Teacher, 9, 29-34.

Flavell, J. H. (1976). Metacognitive aspects of problem solving. In L. B. Resnick (Ed.), The nature of intelligence (pp. 231-236). Hillsdale, NJ: Erlbaum.

Goh, C. (2008). Metacognitive instruction for second language listening development: theory, practice and research implications. RELC Journal: A journal of language teaching and research in Southeast Asia, 39, 188-213. http://dx.doi.org/10.1177/0033688208092184

Goh, C. (2002). Learners' self-reports on comprehension and learning strategies for listening. Asian Journal of English Language Teaching, 12, 46-68.

Goh, C., \& Taib, Y. (2006). Metacognitive instruction in listening for young learners. ELT Journal, 60, $222-232$. 
http://dx.doi.org/10.1093/elt/ccl002

Griffith, P. L., \& Ruan, J. (2005). What is metacognition and what should be its role in literacy instruction? In S. Isreal, C. Block, K. Bauserman, \& K. Kinnucan-Welsch (Eds.), Metacognition in literacy learning: theory, assessment, instruction, and professional development (pp. 3-18). Mahwah: Lawrence Erlbaum Associates.

Herron, C., Cole, S., York, H., \& Linden, P. (1998). A comparison study of student retention of foreign language video: declarative versus interrogative advance organizers. Modern Language Journal, 82, 237-247. http://dx.doi.org/10.1111/j.1540-4781.1998.tb01197.x

Hulstijn, J. H. (2001). Intentional and incidental second language vocabulary learning: a reappraisal of elaboration, rehearsal and automaticity. In P. Robinson (Ed.), Cognition and second language instruction (pp. 258-286). Cambridge: Cambridge University Press. http://dx.doi.org/10.1017/CBO9781139524780.011

Larson-Hall, J. (2010). A guide to doing statistics in second language research using SPSS. London : Routledge . Lynch, T. (2011). Academic listening in the 21st century: reviewing a decade of research. Journal of English for Academic Purposes, 10, 79-88. http://dx.doi.org/10.1016/j.jeap.2011.03.001

Lynch, T. (1998). Theoretical perspectives on listening. Annual Review of Applied Linguistics, 18, 3-19. http://dx.doi.org/10.1017/S0267190500003457

Mendelsohn, D. (2006). Learn how to listen using learning strategies. In U. J. Esther \& A. Martines Flor (Eds.), Studies on language acquisition: current trends in the development and teaching of the four language skills (pp. 75-90). Berlin, GER: Walter de Gruyter.

Mendelsohn, D. (2001). Listening comprehension: we've come a long way, but.... Contact, 27, 33-40.

Mendelsohn, D. (1994). Learning to listen: a strategy-based approach for second language learner. San Diego: Dominie Press.

Pressley, M. (2002). Metacognition and self-regulated comprehension. In A. Farstrup \& S. Samuels (Eds.), What research has to say about reading instruction (pp. 291-309). Newark, DE: International Reading Association.

Rost, M. (2002). Teaching and researching listening. London: Longman.

Scovell, D., Pastellas, V., \& Knobel, M. (2004). 404 essential tests for IELTS general training module. Adams and Austen Press - Sydney, Australia.

Vandergrift, L. (2006). Second language listening: listening ability or language proficiency. Modern Language Journal, 90, 6-18. http://dx.doi.org/10.1111/j.1540-4781.2006.00381.x

Vandergrift, L. (2004). Listening to learn or learning to listen? Annual Review of Applied Linguistics, 24, 3-25. http://dx.doi.org/10.1017/S0267190504000017

Vandergrift, L. (2003). Orchestrating strategy use: toward a model of the skilled second language listener. Language Learning, 53, 463-496. http://dx.doi.org/10.1111/1467-9922.00232

Vandergrift, L., \& Tafaghodtari, H. M. (2010). Teaching L2 learners how to listen does make a difference: an empirical study. Language Learning, 60, 470-497. http://dx.doi.org/10.1111/j.1467-9922.2009.00559.x

VanPatten, B. (1995). Input processing and second language acquisition: on the relationship between form and meaning. In P. Heshimipour, R. Maldonaldo, \& M. van Naerssen (Eds.), Festschrift for Tracy David Terrell (pp. 170-183). New York: McGraw-Hill. .

Wenden, A. (2002). Learner development in language learning. Applied Linguistics, 23, 32-55. http://dx.doi.org/10.1093/applin/23.1.32

Wilson, M. (2003). Discovery listening-improving perceptual processing. ELT Journal, 57, 335-343. http://dx.doi.org/10.1093/elt/57.4.335 